\title{
Erilainen oppijuus haasteena ja voimavarana
}

\author{
SEIJA HAAPASALO
}

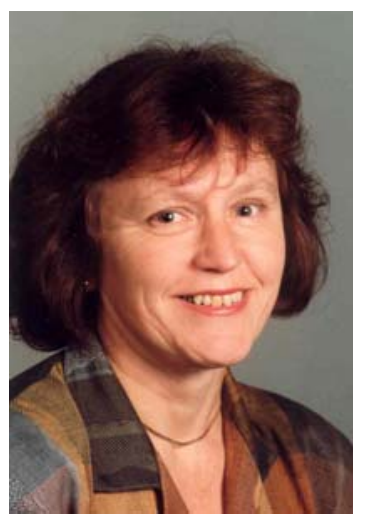

Oppimisvaikeuksien kirjo on laaja ja ne kasautuvat erilaisina yhdistelminä eri yksilöllä. Niinpä elävässä elämässä on vaikea löytää kahta samanlaista "erilaista oppijaa". Lisäksi jokaisella yksilöllä on oma kehityshistoriansa, omat harrastuksensa ja mieltymyksensä, joihin liittyen toinen on harjoittanut enemmän, toinen vähemmän omia taitojaan, sekä vahvuuksiaan että heikkoja kohtiaan. Tästä syystä erilaisen oppimisen ja oppimisvaikeuksien ilmenemismuodot ovat hyvin moninaisia. Ne tarjoavat monenlaisia haasteita, joskin myös voimavaroja ja mahdollisuuksia, jos asiat nähdään laaja-alaisesti.
Se, e, miten oppimisvaikeudet ilmenevät työelämässä ja vaikuttavat työtehtäviin, riippuu toisaalta yksilöllisten vaikeuksien ilmenemismuodoista ja toisaalta siitä, mitkä ovat asianomaisen konkreettiset työtehtävät. Aiemmin, kun oppimisvaikeuksia ei vielä osattu tunnistaa, puhuttiin "että Kalle ei ole lukumiehiä, mutta hän on ihan hyvä työmies". Tuolloin yhteiskunnassa vielä löytyi oikeita käsillä tehtäviä töitä, joissa selviytyi hyvin ilman kynä- ja paperihommia. Vielä runsas kymmenen vuotta sitten varastomiehen työt olivat työtä, joihin ammatinvalinnan ohjauksessa saatettiin ohjata oppimisvaikeuksia omaavia nuoria, koska työssä ei tarvittu luku- ja kirjoitustaitoja. Nykyisin atk-järjestelmät alalla kuin alalla takaavat sen, että lukiongelmaisella ei ole helppoamissään.

Kun lukivaikeudet ilmenevät lapsilla lukemaan ja kirjoittamaan oppimisen vaikeuksina ja virheellisyytenä, niin aikuisilla ilmenemismuodot hieman muuttuvat. Hyvän koulujärjestelmän vuoksi kaikki peruskoulun käyneet oppivat kyllä auttavasti lukemaan ja kirjoittamaan. Haasteena onkin se, ettei auttava luku- ja kirjoitustaito enää riitä nykyajan yhteiskunnassa.

\section{Haasteita riittää}

Monet aikuiset kuvaavat suurimpina vaikeuksi- naan nykyajan työelämässä asioiden kirjallisen ilmaisun työläyden, lukemisen hitauden ja vieraiden kielten vaikeudet. Asioiden paperille paneminen, siis kirjallinen ilmaisu vaatii aivan erilaista kielellistä valmiutta kuin asioiden esittäminen puhumalla. Monelle tuottaa tuskaa aivan pienikin kirjallinen ilmaisu, esim. erilaisten tilauslappujen täyttäminen tai hoitoalalla raporttien kirjoittaminen muutamalla sanalla tai lauseella. Usein tuskaa tuottaa nimenomaan epävarmuus omasta tuotoksesta ja pelko ja häpeä siitä, mitä muut ajattelevat, jos "käsiala on kauheaa ja tekstissä esiintyy virheitä". Tärkeitä kirjoituksia täytyy tarkistuttaa muilla, joskin oikolukuohjelmat helpottavat jo huomattavasti monien elämää.

Työelämässä uusien asiakokonaisuuksien hahmottaminen, laajojen materiaalien lukeminen, omaksuminen ja tiivistäminen sekä vieraskieliset tekstit vaativat oppimisvaikeuksia omaavilta usein tavallista enemmän aikaa. Monet akateemisissa ammateissa, esim. lääkärinä, psykologina tai lakimiehenä toimivat erilaiset oppijat kokevat todella työläinä ja stressaavina lausuntojen kirjoittamisen ja toisaalta laajojen kirjallisten taustapapereiden, muistioiden tai pöytäkirjojen lukemisen sekä niistä mahdollisesti tehtävien yhteenvetojen laatimisen. Kun lausunnot viivästyvät ja työt ruuhkautuvat, on kierre val- 
mis omalle burn outille ja masennukselle. Monet erilaiset oppijat ovat koko opiskelu- ja työelämänsä tehneet "ylitöitä", siis käyttäneet kapasiteettiaan täydellä teholla ja "yläkanttiin". Jos ei pysty tai muista huolehtia riittävästä palautumisesta ja lepolomista, tällaisessa tilanteessa uhkaa helposti kuormittuminen eikä varakapasiteettia enää riitä ylimääräisten haasteiden edessä.

Kielellisiin vaikeuksiin liittyy usein myös kielellisen muistin vaikeuksia. Monet valittavat lyhytkestoisen muistin heikkoutta - siis yhdellä kertaa ei pysty pitämään mielessään montaa asiaa. Aivan sama pätee kielellisen materiaalin, nimien ja terminologian tai puhelinnumeroiden oppimiseen. Monille erityisen hankalia ovat vierasperäiset termit tai vierasperäisiä kirjaimia sisältävät nimet.

Nykyajan työelämässä vierasperäisten materiaalien ja nimikkeiden määrä on räjähdysmäisesti lisääntynyt aivan lähivuosina; siivousalalla on erilaisia kemikaaleja ja puhdistusaineita, hoitoalalla lääkkeitä, vahtimestareilla erilaisiin tulostimiin ja kopiokoneisiin tarvittavia papereita ja kalvoja, joiden pakkaukset ja koodit on opittava erottamaan toisistaan. Onneksi monet voivat käyttää hyödykseen myös visuaalista muistiaan, joka saattaa olla kielellistä muistia parempi. Näin ollen saattaa olla tavallista, ettei henkilö muista ulkoa materiaalin tai tarvikkeen nimeä sinänsä, mutta pystyy hyvin tunnistamaan oikean pakkauksen muiden ulkonäkömerkkien tai värien pohjalta - niin kauan kuin ne pysyvät ennallaan.

Paitsi kielelliset pulmat oppimisvaikeuksien kirjoon liittyvät myös matematiikan vaikeudet, keskittymisen ja tarkkaavaisuuden ongelmat sekä erilaiset hahmottamisen ja motorisen toiminnan hankaluudet. Matematiikan perustaitoja vaaditaan monilla aloilla itse työn suorittamisessa. Esimerkiksi ruuanlaitossa ja leipomotyössä mittasuhteiden hallinta on työn perusvaatimuksia. Kun tehdään isompia ja pienempiä annosmääriä, raaka-aineiden suhteiden on säilyttävä oikeina. Lähihoitajatyön ja -opiskelun keskeisiä pullonkauloja ovat lääkelaskut. Vaikkei jokainen lähihoitaja niitä työssään tarvitsekaan, opiskelussa niistä on selviydyttävä.

Näköhahmottaminen ja käsien taidot kehittyvät yhdessä ja myös niihin liittyvät vaikeudet ovat usein yhteen kietoutuneita. Puhutaankin silmän ja käden yhteistyötaitojen tai visuomotoriikan ongelmista, jotka näkyvät erilaisissa käsien taidoissa ja piirtämisessä. Joskus ongelma on enemmän näköhahmottamisen puolella, jolloin silmät eivät pysty riittävän hyvin ohjaamaan käsien toimintaa. Joskus taas kyse on enemmän motorisen toiminnan epävarmuudesta ja kömpelyydestä. Erittäin monilla ammatillisilla aloilla tarvitaan rakennepiirustusten lukemista, ymmärtämistä ja niiden piirtämistä. Joillain aloilla taas tarvitaan enemmän avaruudellista tilan tai karttojen ja pohjapiirrosten hahmottamista.

\section{Salaileminen vie voimia}

(S) Ise oppimisen vaikeuksia suurempaa tuskaa voivat tuottaa ongelmaan liittyvä sosiaalinen häpeä ja itsetunnon ongelmat. Jos Ruotsin kruununprinsessa Viktoria on lukihäiriönsä vuoksi kokenut olevansa "tyhmä ja hidas", ei ole ihme, että vastaavaa kokevat tavallinen Maija ja Matti, joiden kouluaikana vaikeuden luonnetta ei ehkä edes ymmärretty, puhumattakaan kuntoutuksen mahdollisuuksista. Monia on kiusattu ongelmasta ja moni haluaakin säilyttää salaisuutensa opinnoissaan ja työpaikallaan niin kauan kuin suinkin mahdollista. Omasta oppimisvaikeudesta kertominen työpaikalla ei ole edelleenkään kovin yleistä. Moni pelkää joutuvansa "erityistarkkailun" alaiseksi tai jopa irtisanotuksi.

Kuitenkin vaikeuksien salaaminen kuluttaa huomattavan määrän henkistä energiaa hukkaan. Opiskelijalta saattaa kulua aikaa pelkästään sen pelkäämiseen, ettei vain joutuisi kirjoittamaan fläppitaululle mitään tai esittämään omia ajatuksiaan tai tuotoksiaan ääneen muiden edessä. Eräs päiväkodissa työskennellyt työntekijä kertoi, että kun oli tulossa oma vuoro lukea lapsille päiväunisatu, koko edellinen ilta meni sen jännittämiseen ja sadun lukemisen harjoittelemiseen. Hän oli ollut samassa päiväkodissa 30 vuotta ja salannut vaikeutensa koko ajan (Haapasalo \& Salomäki 2000).

Sekä vaikeuksien salaaminen ja häpeäminen että myös itse kognitiiviseen toimintaan liittyvä hitaus ja työläys voivat aiheuttaa ja ylläpitää melkoista stressitilaa, minkä tiedetään selkeästi ehkäisevän oppimista. Lukiongelmaiset kuvaavat vaikeuksinaan myös jatkuvaa epävarmuutta oman muistinsa suhteen, jolloin muistiinsa ei voi luottaa. Kun oppimisessa ei tapahdu kovin nopeasti ns. automatisoitumista, samoja asioita joutuu kertaamaan, varmistamaan ja tarkistamaan tuon tuosta. Yleisesti ottaen lukihäiriöinen joutuu tekemään opiskelussaan ja työssään monin- 
kertaisen työmäärän ns. normaalilukijaan verrattuna. Joskus asialla saattaa olla tietenkin valoisa puolensakin, kun ei uraudu tai rutinoidu yhtä helposti, vaan voi löytää joskus uusia, luovia ratkaisujakin.

\section{Onko koko elämä mennyt omaa alaa etsiessä?}

ppimisvaikeuksien ilmenemistapoihin kuuluu myös ongelmien päällekkäisyys (ns. komorbiditeetti), eli on todennäköistä, että yhdentyyppisen vaikeuden, esim. lukivaikeuden yhteydessä ilmenee vaikeuksia myös muilla alueilla, kuten tarkkaavaisuudessa, matematiikassa tai hahmottamisen tai motoriikan alueella (mm. Lyytinen ym. 2000, Lavikainen 2005). Niinpä oppimisvaikeuksien monimuotoisuus aiheuttaa myös sen, että samalla henkilöllä vaikeuksia voi ilmetä monenlaisissa arkielämän tilanteissa ja työtehtävissä. Tällöin ammatinvalinta ei ole aina kovin yksinkertaista.

Kokemus sekä tutkimustulokset (mm. Lavikainen 2005) kertovat, että monilla oppimisvaikeuksia omaavilla on muita alhaisempi koulutustaso ja he toimivat sen mukaisesti vähemmän vaativissa ammateissa kuin mihin heidän yleinen kyvykkyytensä antaisi mahdollisuuksia. Lukemisen ja kirjoittamisen vaikeudet kouluaikana ovat karkottaneet monen opiskeluhalut niin, ettei edes uskalleta haaveilla pidemmistä opinnoista. Kuitenkin seurauksena voi olla turhautuminen työhön, joka ei anna riittävästi haastetta tai vastaa omia kykyjä. Moni erilainen oppija onkin tehnyt hyvin monimuotoista työuraa kokeilemalla monenlaisia työtehtäviä yrityksen ja erehdyksen kautta.

Ammatinvalinta saattaa muodostua erityisen haastavaksi silloin, kun epäsuhta erityisvaikeuden ja muiden valmiuksien välillä on erityisen suuri. Kun jotkut asiat sujuvat hyvin ja joissakin toisissa on "täysi nolla", se voi vaikeuttaa oman realistisen minäkäsityksen ja identiteetin muodostumista. Itsetuntemuksen vinoutumat voivat tapahtua molempiin suuntiin. Monet leimaavat myös itse itsensä "huonoksi", hitaaksi tai tyhmäksi, jolloin vahvuudetkin voivat jäädä tunnistamatta. Toisaalta nuori voi myös haaveilla täysin epärealistisesta urasta. Tällöin epärealismi voi pitää sisällään esim. sen, että nuori kieltää omat vaikeutensa tai hän ei tunnista omia valmiuksiaan suhteessa ammattihaaveen vaatimuksiin tai ei ole valmis tavoitteen saavuttamisen vaatimaan pitkäjänteiseen ja kovaan työntekoon.

On luonnollista, etteivät erilaisten työtehtävien vaatimukset ole lainkaan itsestään selviä nuorille. Sen lisäksi nekin muuttuvat työelämän muuttuessa nopeassa tahdissa. Monesti vaaditaan konkreettisia työkokemuksia ja sitä kautta saatavaa palautetta, ennen kuin omien kykyjen rajat ja mahdollisuudet sekä myös oma motivaatio alkavat itselle hahmottua. Työkokeilujen lisäksi myös neuropsykologinen tutkimus voi avata asianomaisen silmiä uudella tavalla ja laajentaa huomattavasti omaa itsetuntemusta.

Moni löytää "oman alansa" vasta vuosien kokeilujen jälkeen. Masa jätti ammattikoulun kokkilinjan kesken jo ensimmäisen syksyn aikana, kun lukivaikeus uhkasi paljastua. Sen jälkeen hän päätti hankkiutua sellaiseen ammattiin, jossa ei tarvita pitkiä opiskeluja eikä lukemis- ja kirjoittamistaitoja. Hän ryhtyi bussinkuljettajaksi. Kuitenkin myös matematiikka ja päässälaskut tuottivat vaikeuksia, joten rahastaminen ja rahasta takaisin antaminen ruuhkaisissa busseissa olivat sen verran epävarmoja, etteivät rahat ja tilitykset aina täsmänneet. Masa kokeili myös tilausajoja. Siellä oli ongelmana osoitteiden ja kohteiden löytäminen. Katujen nimikylttejä oli mahdotonta ennättää lukea ajaessa.

Tässä vaiheessa Masa päätti tehdä asialle jotain. Hän hakeutui uudelleen ammattikouluun opiskelemaan ja pääsi samanaikaisesti neuropsykologiseen kuntoutukseen. Kuvallinen ilmaisu oli lähellä Masan sydäntä ja hän ajatteli valokuvauslaborantin alaa itselleen sopivaksi. Hyvin pian kävi kuitenkin ilmi, että alalla vaadittavat kemian opinnot tuntuivat ylivoimaisilta eivätkä jaksaneet riittävästi motivoida. Kuntoutuksen tuella Masa kuitenkin suoritti kolmivuotiset opinnot päätökseen, vaikka tiesi, ettei tulisi ko. alalla työkseen toimimaan. Hän halusi myös näyttää itselleen, että pystyy viemään opintonsa päätökseen. Valmistuttuaan hän hankki työpaikan päiväkodista ja opiskeli vielä oppisopimusjärjestelmällä lähihoitajaksi. Päiväkodissa lasten kanssa hän voi toteuttaa omaa luovuuttaan ja mielikuvitustaan ja Masan ja lasten ilo on molemminpuolista.

\section{Työelämän vaatimukset kasvavat}

Tämän hetken työelämän vaatimustaso on kovaa. Paavo Rissasen sanoin "työelämä on kauniiden 
ja rohkeiden, pintavialliset tai edes viattomat eivät enää tahdo kelvata".Yhteiskunta heittää ulos, syrjäytymään yhä kasvavan osan inmisistä. Työelämässä hyvin selviytyneet erilaiset oppijat ovat selviytyneet siellä usein erityisten lahjojensa tai erityisen kovan työnteon avulla. Monet ovat toimineet ylikapasiteetilla ja ylikuormittuneina pitkiä aikoja. Kun elämässä kasautuvat monet riskitekijät; työtehtävät muuttuvat tai lisääntyvät, työn vaatimustaso kasvaa, yksityiselämässä on huolia ja stressiä, fyysiset sairaudet koettelevat ja iän mukanaan tuoma hidastuneisuus alkaa häiritä, mitta voi olla täysi ja seurauksena masennus ja uupuminen.

Erityisen suuren haasteen tarjoavat työelämässä nykyaikana nopeaan tahtiin tapahtuvat muutokset. Ennen kuin edellisen muutoksen mukanaan tuomia uusia käytäntöjä on edes kunnolla opittu, täytyisi jo taas orientoitua uuteen järjestelmään. Oppimisvaikeuksia omaavilla asioiden oppiminen ja erilaisten menettelytapojen automatisoituminen vie usein tavallista pidemmän ajan. Liian suuret ja nopeaan vaihtuvat työympäristön tai työn tekemisen mallit voivat joskus kuormittaa liikaa, varsinkin ikääntymisen yhteydessä. Henkilö on saattanut kehitellä itselleen omia selviytymiskeinojaan, jotka ovat toimineet vanhoissa, tutuissa toimintaympäristöissä. Työtehtävän tai työympäristön muuttuessa vanhat selviytymiskeinot eivät enää toimikaan ja koko selviytymisstrategia saattaa romahtaa.

Joskus ongelmia tulee eteen, kun henkilö siirtyy vaativampiin tehtäviin, esim. esimiesasemaan. Uudenlaiset organisointi- ja paperityöt tuntuvat tuolloin työläiltä ja vievät runsaasti aikaa. Omien vaikeuksien salailu ja yksin puurtaminen eivät aina ole paras ratkaisu. Onnistuneesta ongelmanratkaisusta on esimerkkinä eräs varastoesimies, joka tässä siirtymävaiheessa lähti sekä uuteen esimiestehtävään valmentavalle kurssille että lukikuntoutuskurssille, josta sai "tsemppiä" ja uskoa omalle jaksamiselleen. Tukijoukkoina toimivat oma vaimo, joka tarkasti opiskelutehtävien kieliasun, sekä työpaikalla sihteeri, joka hoiti paperitöiden rutiinit siellä. Onnistuneeseen haasteiden kohtaamiseen kuuluu olennaisena osana myös se, että osaa ja pystyy käyttämään hyväkseen ympäristön tarjoamia tukimahdollisuuksia.

Kustannustoimittaja oli aikoinaan todennut runoilija Arja Tiaiselle, että tällä taitaa olla sanasokeutta, kun on niin paljon kirjoitusvirheitä, muttei se haittaa, koska sitä varten on maisterit, jotka korjaavat oikeinkirjoitusvirheet.

Työelämän muutosten vaikutukset erilaiselle oppijalle saattavat olla monensuuntaisia. Toisaalta tietokoneet ja muut laitteet tuovat helpotusta itse tehtävän suorittamiseen. Moni erilainen oppija on kokenut tietokoneen oikolukuohjelmineen ja muine apuohjelmineen helpotuksena. Piirustuksia ei enää tehdä käsivaraisesti, vaan tietokoneiden avulla. Toisaalta monimutkaistunut tietotekniikka tuo omat haasteensa kognitiiviselle suorituskyvylle. Ohjelmien sujuva käyttäminen vaatii paljon lähes ulkoa opittavan tiedon hallintaa eikä se ole aina helppoa oppimisvaikeuksia omaavalle.

Nykyajan työelämässä vaaditaan myös entistä itsenäisempää ja myös monipuolisempaa tehtäväkokonaisuuksien hallintaa. Ns. aputyövoima on karsittu työelämästä lähes kokonaan, jonka seurauksena jokaisen työntekijän olisi mielellään oltava monitaituri, joka siirtyy sujuvasti työtehtävästä toiseen ja hoitelee sivussa rutiininomaisesti sihteerin, toimistovahtimestarin ym. tehtävät. Metsurin täytyy itsenäisesti osata kartan avulla suunnistaa oikeaan paikkaan ja kaataa sopivat puut (ilman erillisiä leimauksia) oikealta tontilta eikä naapurin tontilta.

\section{Ikääntymisen haasteet}

\section{ka} misen myötä oppimisvaikeudet usein korostuvat - ehkä monistakin syistä johtuen. Useinhan työtehtävien vaatimustaso kasvaa iän mukana ja toisaalta ikä lisää hidastuneisuutta ja heikentää jossain määrin muistitoimintoja. Ihmisellä on yleensä venymiskykyä ja uuden oppimisen kykyä vielä iäkkäänäkin, kunhan oppimiselle ja muutosvaatimuksille annetaan riittävästi aikaa. Sen sijaan liian nopeatempoisissa työelämän muutospaineissa erilaisilla oppijoilla on selvä ylikuormittumisen riski olemassa.

Uudet tutkimustulokset osoittavat, että lukivaikeuden yhteydessä on kyse myös hermoston normaalia hitaammasta toiminnasta ja/tai aikatarkkuuden ongelmista (Laasonen 2002), jotka ilmenevät eri aistipiirien alueilla. Näkö-, kuuloja tuntoaistin alueella on havaittu, että lukihäiriöisellä on normaalia suurempia vaikeuksia erottaa ajallisesti lähekkäin esiintyviä aistiärsykkeitä toisistaan. Tämän ei-kielellisen aikatarkkuuden on todettu olevan yhteydessä myös kielellisiin toimintoihin, kuten äänteiden käsittelyyn. Ikä heikentää kaikkien henkilöiden aikatarkkuut- 
ta, mutta erityisen paljon lukihäiriöisten. Syynä tähän voivat olla myös lukihäiriöisten normaalia rajallisemmat kompensointimahdollisuudet. On mahdollista, että lukihäiriöiset ovat joutuneet koko ajan kuormittamaan henkisiä resurssejaan kykyjensä äärirajoilla eikä venymiskapasiteettia ole enää yhtä paljoa käytettävissä ikääntymisen vaatimaan kompensaatioon.

Monet elämässään selviytyneet lukihäiriöiset kertovat, että he ovat aina joutuneet tekemään paljon töitä pärjätäkseen. Ahkeran työnteon oppiminen on toisaalta voimavara ja mahdollisuus omien taitojen ja erinomaisuuden kehittämiseen. Mitään huippusaavutuksia ei saavuteta ilman työntekoa. Parhaimmillaan työntekoon liittyvä työn imu (Hakanen 2005) voi jopa suojata ihmistä työn stresseiltä ja työuupumukselta. Työn imun vaalimisessa ja edistämisessä pitäisi Jari Hakasen mukaan suunnata katseet työn voimavaratekijöihin eli työn itsenäisyyden, esimiehen tuen ja arvostuksen kaltaisiin energisoiviin motivaatiotekijöihin. Tarvitaan myös kaikenlaisia joustoja ja yksilöllisiä vaihtoehtoja inmisen elämäntilanteen mukaan. Työn voimavaratekijät ovat useimmiten ilmaisia: maksaa vain vaivan ja tahtotilan antaa palautetta, rohkaista, tukea, lisätä itsemääräämisoikeutta työssä ja kehittää johtamista. Mainitun kaltaiset tukimuodot auttavat myös erilaisia oppijoita.

Inmisen tulisi oppia tunnistamaan oman jaksamisen rajat ja työuupumuksen merkit riittävän ajoissa. Kuntoutusmaailmassa löytyy esimerkkejä tästä, miten esim. korkeasti koulutetut erilaiset oppijat saattavat uupua työtehtävissään ikääntymisen myötä. Usein kokeneilla ja ikääntyvillä työntekijöillä työtehtävien määrällä on myös taipumusta lisääntyä objektiivisestikin mitattuna. Lisäksi varmasti enemmän on niitä esimerkkejä, joiden kohdalla kuormittumisen ja loppuun palamisen taustalla olevia kehityksellisiä oppimisvaikeuksia ei vielä ole lainkaan tiedostettu. Monet erilaiset oppijat eivät itsekään tiedosta yhteyttä lapsuuden oppimisvaikeuden ja työelämässä tapahtuvan ylikuormittumisen välillä. Yleensä ajatellaan, että kun on opittu kuitenkin lukemaan ja kirjoittamaan, lapsuuden aikainen lukivaiva on ohitettu ja parantunut. Kuitenkin oppimisvaikeus saattaa hidastaa kielellistä prosessointia siinä määrin, että nopeaa lukemista ja kirjoittamista vaativissa työtehtävissä piilee myös ylikuormittumisen vaara.

Toisaalta ikääntyminen tuo tullessaan myös myönteistä kehitystä. Ymmärtämystä ja kokonaisnäkemystä vaativissa asioissa myös ikääntyvä erilainen oppija voi olla vahvoilla. Jotkut onnelliset ovat päässeet sellaiseen työasemaan, että voivat käyttää sihteereitä tai muuta aputyövoimaa hoitamaan tekniset asiat. Työelämässä on puhuttu ikääntyvän ja nuoren työntekijän muodostamasta yhteisestä tiimistä, joissa eri-ikäiset työntekijät voisivat sopivasti täydentää toinen toisiaan ja kokeneemman taidot ja ns. hiljainen tieto voitaisiin saada siirretyksi nuoremman haltuun. Tämäntyyppisen parityöskentelyn uusien muotojen kehittely voisi tarjota myös oivallisia mahdollisuuksia ikääntyvien erilaisten oppijoiden työuran jatkamiselle ja ennenaikaisten työkyvyttömyyseläkkeiden ennaltaehkäisyyn.

\section{Peilin kääntöpuoli, erilaisuudesta voimaa ja luovuutta}

$\mathrm{O}_{\mathrm{B}}$ ppimisvaikeuksia ilmenee kaikissa yhteiskunta-, ikä-, lahjakkuus- ja ammattiryhmissä. Monet huippulahjakkaat ja luovat taiteilijat voivat olla ns. erilaisia oppijoita siinä missä yhteiskunnasta syrjäytynyt työtön tai vanki. Kannustaako oppimisvaikeus erityisesti luovuuden kehittymiseen, kun ns. normaali tapa oppia ei suju ja on käytettävä omaa luovuuttaan ja kekseliäisyyttään omien, erilaisten toimintamallien kehittämisessä? Tai onko oppimisvaikeudessa kyse erilaisesta maailman hahmottamistavasta?

Tehokas henkinen toiminta ja oppiminen perustuvat aivojen ei osien sekä oikean ja vasemman aivopuoliskon joustavaan ja sujuvaan yhteistyöhön. Monet tutkimustulokset osoittavat, että oikean ja vasemman aivopuoliskon toimintatyylit ovat keskenään hieman erilaisia. Vasemmassa aivopuoliskossa työstetään yksityiskohtia ja perättäistä informaatiota, joita tarvitaan mm. lukemisen ja kirjoittamisen hallinnassa (esim. Byring, Haapasalo \& Salmi 2004 a). Oikean aivopuoliskon tehtäviin kuuluu taas suurempien kokonaisuuksien hallinta. On myös mahdollista, että inmiset eriyttävät omaa toimintaansa tukeutuen enemmän jompaankumpaan aivopuoliskoon tai että lukemisessa ja kirjoittamisessa tarvittavan vasemman aivopuoliskon kehitys jostain syystä viivästyy tai kehittyy oikeaa heikommin/ hitaammin. Niinpä ilman erityisen suuria aivotoiminnan häiriöitäkään osa inmisistä saattaa toimia luonnostaan enemmän oikean aivopuoliskon kokonaisvaltaisen toimintamallin varassa myös 
lukemis- ja kirjoittamistoiminnoissa (esim. Byring, Haapasalo \& Salmi 2004 b). Tuolloin yksityiskohtainen kielellinen tarkkuus voi olla heille työlästä opittavaksi. Sen sijaan toimintamalleina korostuvat piirteet, joita on liitetty oikean aivopuoliskon toimintoihin; ei-kielellinen kuvallinen ja suoraan aistimaailman kokemuksiin perustuva kokemusmalli ja intuitio, uteliaisuus, luovuus. Näiden avujen varassa voidaan kokeilla ja luoda uutta, mutta ehdollistuva oppiminen ja mekaaninen ulkoa oppiminen ovat työläitä.

Monelle lukivaikeuksiselle kielellinen ns. ulkoa oppiminen on työlästä, vieraan kielen sanat ja kertotaulu eivät tahdo jäädä päähän. Niinpä oppimisen tueksi voi kehitellä mielikuvituksellisia muististrategioita tai pyrkiä ymmärryksen ja logiikan avulla korvaamaan muistin heikkoutta. Kertotaulua ei tarvitse osata ulkoa, vaan sen voi näppärästi laskea yhteen- ja vähennyslaskujen sekä muutamien "knoppien" avulla. Asioiden ymmärtämiseen panostaminen voi palkita oppimiseen käytetyn ajan myöhemmin moninkertaisesti. Asian ymmärtäminen mahdollistaa erilaiset käyttö- ja sovellutusmahdollisuudet aivan eri tavalla kuin pelkkä mekaaninen ulkoa oppiminen.

Oppimisvaikeuksien yhteydessä puhutaankin usein ns. automatisoitumisen vaikeudesta. Niin kiusalliselta kuin vaiva kuulostaakin ja usein käytännössä onkin esim. lukemisen ja kirjoittamisen perustaitojen osalta, tälläkin asialla voidaan nähdä kääntöpuolensa joissain muissa tilanteissa. Kun opittu asia ei ole automatisoitunut, asiaan joutuu syventymään ja paneutumaan uudestaan uusissa tilanteissa. Tuolloin uudet asiayhteydet ja tilanteet todennäköisesti tuovat uutta ilmettä tai painotusta, jolloin uusi ratkaisu tai johtopäätös tai sovellutus voikin olla hivenen erilainen, luovempi tai muuten tilanteeseen paremmin sopiva.

Erilaisten aivosairauksien ja aivovaurioiden yhteydessä nähdään ja koetaan joskus todellisia inmetarinoita siitä, miten aivot tuottavat tarvittaessa kompensaatio- ja selviytymiskeinoja. Kun yksi kanava tukkeutuu, avautuu mahdollisuuksia uudelle, erilaiselle tavalle toimia ja voi syntyä uudenlaisia innovaatioita. Samoin oppimisvaikeuksia omaavat inmiset ovat kehitelleet itselleen monenlaisia luovia selviytymiskeinoja, joita tulisikin entistä tehokkaammin myös tietoisesti hyödyntää erityisopetuksen ja työelämän tukikeinojen kehittämisessä.

\section{Onko epäonnistuminen}

mahdollisuus? Kuinka kierrän kiven?

$Y$

ksi selviytyjän tunnusmerkki on se, että osaa kääntää epäonnistumisen mahdollisuudeksi. Luovat selviytyjät voivat epäonnistua useinkin, mutta osaavat kaatua eteenpäin. Useinhan on kysymys vain tulkinnoista - mikä on epäonnistumista, mikä vain yksi kokemus muiden joukossa ja mikä ehkä onnekas mahdollisuus oppia tärkeitä uusia asioita.

Näihin päiviin asti on koulussa ja työelämässä pyritty virheiden välttämiseen ja virheistä on rangaistu. Erilainen oppija, jolle virheitä yleensä on kasautunut muita enemmän, on usein joutunut kärsimään omasta erilaisuudestaan; hänet on nostettu silmätikuksi kielteisellä tavalla, häntä on kiusattu tai hän on joutunut häpeämään virheitään. Häpeän ja pelon ilmapiirissä ei ole helppoa oppia. Toisaalta teatterin ja esittävän taiteen alueella tästäkin kokemuksesta voi olla hyötyä. Eräs ohjaaja oli kiinnittänyt huomiota siihen, oppimisvaikeuksista kärsineet näyttelijät pystyvät muita paremmin eläytymään voimakkaiden, kielteisten tunnetilojen esittämiseen.

Seuraava esimerkki kahdesta päiväkodin työntekijästä valaisee erilaisten tulkintojen ja suhtautumistapojen merkitystä erilaisen oppijan maailmassa. Jo aiemminkin mainittu päiväkodin työntekijä oli salannut oppimisvaikeuttaan työpaikallaan 30 vuoden ajan ja peläten asian ilmituloa keksinyt tekosyitä siihen, ettei voi kirjoittaa fläppitaululle eikä toimia sihteerinä kokouksissa. Samoin lapsille luettavaa satua oli täytynyt harjoitella edellisenä iltana, jottei asia olisi paljastunut lapsille. Toinen päiväkodin työntekijä käytti kekseliäisyyttään toisin. Hän "luki" lapsille tuttuja satuja tahallaan "väärin", siis eri tavoilla, keksien itse uusia versioita saduista. Ja kaikilla oli hauskaa.

Omien, itselle sopivien oppimistapojen löytäminen on erityisen tärkeätä erilaisille oppijoille. Kirjailija Kirsti Mannisen sanoin "on löydettävä oma polku, jota pitkin voi kiertää kiven". Hän oli itse oppinut lukemaan ennen kouluun menoa jollain omalla kokonaisvaltaisella "tekstin valokuvaamistekniikalla". Sen vuoksi hän ei enää oppinut lainkaan äänteiden hahmottamisen kautta tapahtuvaa lukutaitoa, jonka vuoksi hänen oikeinkirjoitustaitonsa jäi epätarkaksi. Hän oli jo nuorena opetellut kirjoituskoneella kymmensormijärjestelmän mukaisen kirjoitustaidon, joka on 
vuosien varrella kehittynyt aivan automaattiseksi toiminnaksi suoraan "alitajunnasta kirjoituskoneelle". Virheiden korjaamiseen hän voi käyttää oikolukuohjelmia tai toisia henkilöitä. Olennaista onkin, ettei jää teknisten virheiden orjaksi, vaan pystyy näkemään luku- ja kirjoitustaidon vain apuvälineenä, ei pääasiana.

Oppimisvaikeus voidaan nähdä myös sisäisenä mallina tai prosessina, joka opitaan kehityksen myötä vuorovaikutuksessa ympäristön kanssa (Kokkinen 2005). On olennaista, millaisena itse näkee ja kokee oman oppijuutensa ja sen "erilaisuuden". Jos tuomitsen itseni lukihäiriöiseksi ja sen takia oppimiskyvyttömäksi, saatan antaa itselleni elinikäisen tuomion olla oppimatta kiinnostavia asioita. Uskomukset omasta oppimisesta voivat tehokkaasti edistää tai ehkäistä oppimista. Vielä uskomuksiakin vahvemmin oppimiseen vaikuttavat omat arvot siitä, mikä on tärkeää ja minkä eteen kannattaa nähdä vaivaa sekä oma identiteetti. "Lukihäiriöisen identiteetti" määrittelee ja ohjaa henkilön toimintoja paljon enemmän, kuin mitä tapahtuu henkilöllä, jolla lukivaikeus on vain tietynlainen toimintatapa, käytännön hidaste joissain asioissa.

Kun pystyy näkemään oman erilaisuutensa voimavarana, ei lannistu tai masennu vaikeuksien alle, vaan pystyy ehkä näkemään lantin kääntöpuolen, pohtimaan asioita uudella tavalla ja kehittelemään vaihtoehtoisia, luovia tapoja oppia. On mahdollista, että lahjakkaat, pitkälle päässeet erilaiset oppijat ovat päässeet huipulle nimenomaan tästä syystä. Kun oppiminen ei tapahdu automaattisesti ja sanojen merkitykset eivät aukea tai painu mieleen nopeasti, joutuu syventymään asioihin ja niiden keskinäiseen logiikkaan perusteellisemmin kuin sujuva lukija. Hyvän oppimistuloksen kannalta ovat olennaisia oppijan aktiivinen rooli sekä kaikkien aikaisempien tietojen, taitojen ja uskomusten hyödyntäminen.

\section{Lähteet ja kirjallisuutta}

Byring RF, Haapasalo S \& Salmi T (2004 a)

Adolescents with learning disorders have atypical EEG correlation indices. I. Correlation indices during visual discrimination. Clinical Neurophysiology, Vol 115 (2004) 2574-2583.

Byring RF, Haapasalo S \& Salmi T (2004 b) Adolescents with learning disorders have atypical EEG correlation indices. II. Correlation indices during reading. Clinical Neurophysiology, Vol 115 (2004) 2584-2592.
Haapasalo S (2004) Lupaavia kokemuksia

LUKKI -kuntoutuksesta. Kuntoutus 1, 22-33.

Haapasalo S \& Salomäki J (2000) "On kuin kivi olisi vierähtänyt sydämeltä". Kokemuksia aikuisten erilaisten oppijoiden ryhmäkuntoutuksesta. Kuntoutussäätiön tutkimuksia 64.

Hakanen J (2005) Työuupumuksesta työn imuun: työhyvinvointitutkimuksen ytimessä ja reuna-alueilla. Sosiaalipsykologian väitöskirja, Helsingin yliopisto.

Hintikka A-M (toim.) (2000) Erilaisesta oppijasta erinomaiseksi oppijaksi. Kokemuksia erilaisesta opettamisesta ja erilaisesta oppimisesta. Helsingin seudun erilaiset oppijat ry, HERO.

Kokkinen A(2005) Lukivaikeus osana elämää. Miten lukivaikeus näyttäytyy elämänkulussa? Aikuiskasvatustieteen pro gradu -tutkielma. Kasvatustieteen laitos, Helsingin yliopisto.

Kromosomeista kaksoiskonsonantteihin: Lukibussin matkakirja (2004). Suomen Kuntaliitto.

Laasonen M (2002) Temporal acuity in developmental dyslexia across the life span: Tactile, auditory, visual, and crossmodal estimations. Academic dissertation. Department of Psychology, University of Helsinki.

Lavikainen H (2005). Itseraportoitujen koulunkäynti- ja oppimisvaikeuksien yleisyys ja yhteydet lapsuuden ja nuoren aikuisuuden elämäntilanteisiin ja koettuun terveyteen. Terveyskasvatuksen pro gradu -tutkielma, Jyväskylän yliopisto, Terveystieteiden laitos.

Lehtoranta P, Leivo H \& Haapasalo S (2003). Miten ohjaat työssäoppijoita. Kuntoutussäätiö.

Leinonen S (1997) Lukivaikeus esteenä elämänvalinnoille? Kuntoutus 4, 18-24.

Lyytinen H, Ahonen T, Aro M, Aro T, Holopainen L, Närhi V \& Räsänen P (2001) Kehitysneuropsykologinen näkökulma oppimisvaikeuksiin. Teoksessa P. Fadjukoff, T. Ahonen \& H. Lyytinen (toim.) Oppimisvaikeudet, tutkimuksesta käytäntöön (s.24-58). Niilo Mäki Instituutti.

McNulty MA (2003) Dyslexia and the Life Course. Journal of Learning Disabilities, Vol. 36, 4, 363-381.

Tanhua E (2002) Kekseliäisyys käyttöön oppimisvaikeuksissa. Työ, terveys, turvallisuus 6, 36-38. 